\title{
Purge Ventilation Operability (U)
}

by

J. R. Marella

Westinghouse Savannah River Company

Savannah River Site

Aiken, South Carolina 29808

DOE Contract No. DE-AC09-89SR18035

This paper was prepared in connection with work done under the above contract number with the U.S.

Department of Energy. By acceptance of this paper, the publisher and/or recipient acknowledges the U.S. Government's right to retain a nonexclusive, royalty-free license in and to any copyright covering this paper, along with the right to reproduce and to authorize others to reproduce all or part of the copyrighted paper. 


\section{DISCLAIMER}

This repore was prepared 2520 account of work sponsored by 2 a ageacy of the United States Government. Neither the United States Governmeat aor any agency thereof, aor any of their cmployees, makes eny wartenty. express or implied. or assumes any legal lizbility or respoasibility for the accuracy. compleceness, or usefulacss of any information, 2pperatus, product, or process disclosed, or represents that its use would not infriage privately owned rights. Reference herein to any specific commercial product, process, or service by trade name, trademark. manufacturer, or otherwise docs not accessarily constiture or imply its cadorscmeat, recommendetion, or favoring by the Uaited States Government or zny agency thereof. The views, and opinions of authors expressed terein do not accessarily state or reflect those of the United States Goverameat or any ageacy ihereof.

This repor has been reproduced directly frow the best available copy.

Available to DOE and DOE contractors from the Office of Scientific and Technical laformation. P. O. Box 62. O2k Ridge, TN 37831; prices avilable from (615) $576-8401$.

Aveileble to tho public from tho Netional Tecbnical Information Service. U. S. Deperment of Commerco, S285 Port Royal Rd. Springfield. VA 22161 


\section{DISCLAIMER}

Portions of this document may be illegible in electronic image products. Images are produced from the best available original document. 
G. T. Wright, 703-H

T. L. Lex, 719-4A

H. Handfinger, 704-56H

W. A. Morrison, 241-100F

T. M. Monahon, 703-H

V. G. Dickert, 703-H

C. A. Polson, 707-H

B. G. Croley, 241-119H

G. Davis, 241-100F

R. L. Salizzoni, 707-H

W. C. Clark, 241-119H

G. D Thaxton, 241-119H

W. F. Bates, 703-H

D. M. Grimm, 707-H

M. A. Ceravolo, 707-H (2cc)

A. W. Wiggins, $241-84 \mathrm{H}$

B. R. Hess, 241-102F (2cc)

S. A. Saunders, 241-102H

T. L. Ortner, $241-152 \mathrm{H}$

M. D. Johnson, 704-56H

J. E. Marra, 703-H

E. Saldivar, 703-H

B. L. Lewis, 703-8C

T. B. Caldwell, 703-6C

J. B. Guilherme, 703-H

K. A. Hauer, 241-100F

J. A. Pike, 707-H

T. R. Jones, 707-H

J. D. Nguyen, 703-H

J. D. Carlson, 703-H

P. d'Entremont, 703-H

J. Cato, 241-100F

C. G. Lampley, 241-100F

W. A. Lanham, 707-H

J. W. Smith, 705-1C
HLWE File Room, 703-H

File Code: 175.1.2

Records Mngt., 773-52A(4cc) 
HIGH LEVEL WASTE ENGINEERING

SUPPORT SYSTEMS ENGINEERING
WSRC-TR-94-0506

REVISION: 0
UNCLASSIFIED

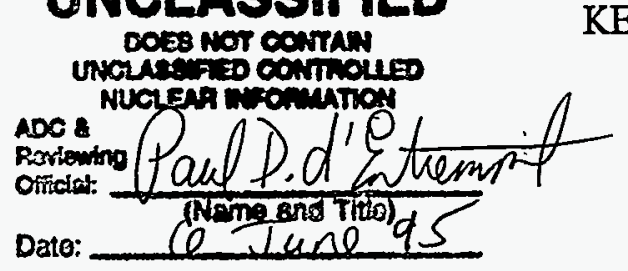

KEYWORDS:

RETENTION:
Purge

Exhaust

Ventilation

Fan

Filter

Lifetime

?

CLASSIFICATION: Unclassified

$\underset{\substack{\text { Authorized Derivative } \\ \text { Classifier }}}{\text { Paul d'Etremm }}$

PURGE VENTILATION OPERABILITY (U)

BY

J. R. MARELLA

ISSUED: 4/10/95

Ooh R Manila

Afthor/Authenticator

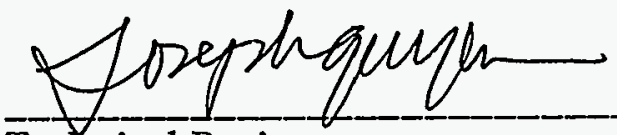

Technical Reviewer
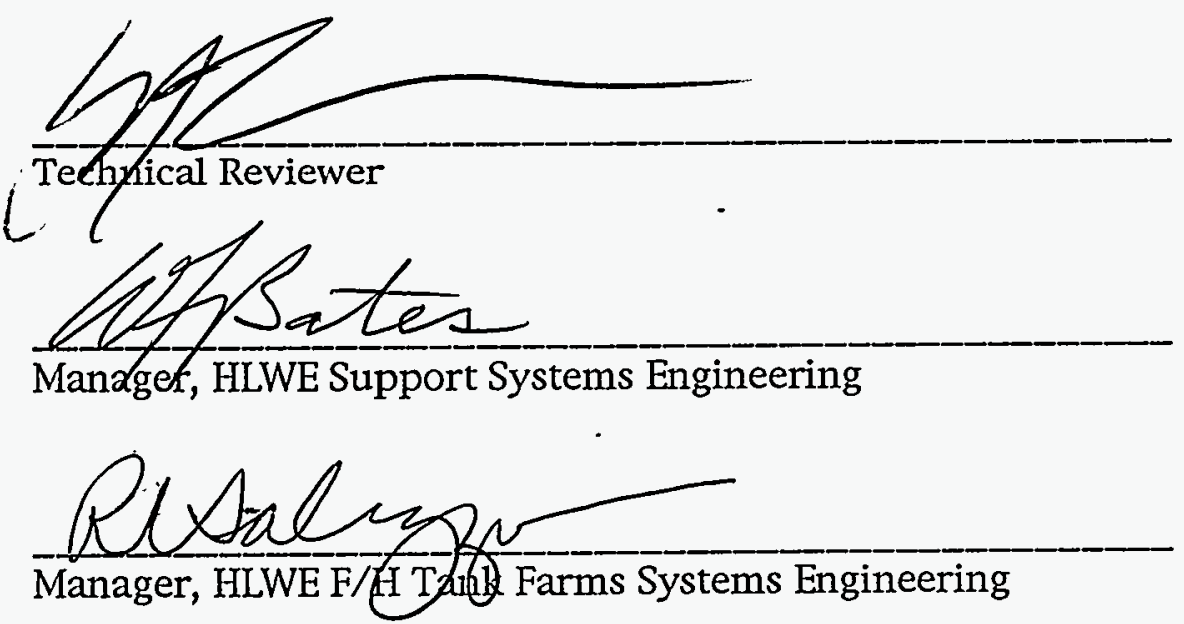

Date: $4 / 10 / 95=$

Date:4/10/95

Date: $4 / 10 / 95$

Date: $5 / 17 / 95$

Date: $5 / 22 / 95$<smiles>CCCC</smiles> 
WSRC-TR-94-0506, Rev. 0

Page 2 of 8

$4 / 10 / 95$

\section{INTRODUCTION}

In response to a recent H Tank Farm area Shift Technical Engineer (STE) request, a determination of minimum requirements for purge exhaust ventilation system operability has been performed. HLWE and HLW Regulatory Program personnel have evaluated the various scenarios of equipment conditions and HLWE has developed the requirements for purge exhaust systems. This report is provided to document operability requirements to assist Tank Farm personnel to determine whether a system is operable/inoperable and to define required compensatory actions.

\section{$\underline{\text { SUMMARY }}$}

All ventilation systems installed on HLW tank (except annulus ventilation) and transfer systems are used to serve one and/or both purposes: (1) to prevent or minimize the spread of airborne particulate radioactive material, and (2) to prevent the accumulation of explosive or flammable mixtures anywhere in the facilities.

The purge exhaust ventilation consists of an exhaust fan, HEPA filter unit, reheater, water cooled condenser (on most systems) and a demister (on most systems) along with support systems consisting of steam for the preheater, and chromate cooling water for the water cooled condenser. In addition to the permanently installed purge exhaust ventilation systems, the tank farms also maintain dedicated portable backup ventilation units for use in emergencies as required by OSR (Reference 2).

When an adverse condition which affects the operation of the heater, condenser or both is discovered, the ventilation system can be declared "Operable" as long as all the following elements are met:

1. The air flow (nominally) $100-300 \mathrm{CFM}$ is established.

2. The interior pressure is maintained slightly negative per current operating procedure limit with respect to atmosphere.

3. A permanent or portable CAM/air sampler is in operation monitoring exhaust airstream.

4. HEPA filters in the permanently installed unit are installed and have been DOP tested when replaced within the OSR specified frequency (including backup ventilation system, when installed).

5. HEPA filter dP does not exceed the upper limit and is above its lower limit.

It is concluded that demister high $\mathrm{dP}$, loss of chromate (cooling) water to the condenser and/or steam to the reheater do not affect system operability if all the specified elements are met.

Although HLWE conservatively defines system inoperability if HEPA filter dP is out of limit high, OSR compliance is maintained due to the fact that air flow, tank vacuum, LFL Hydrogen less than 10\%, Radiation Monitoring and HEPA filter DOP test are maintained.

The compensatory actions for degraded exhaust system scenarios are included in the Discussion section. 
WSRC-TR-94-0506, Rev. 0

Page 3 of 8

$4 / 10 / 95$

\section{GENERAL INFORMATION}

Typical installations on the type I and type II tanks include an exhaust fan, HEPA filter, reheater and condenser. The exceptions to this arrangement are tanks 1, 2, 3, 9, 10 and 13 which, in addition, have a shell type demister. Typical installations on type III and IIIA tanks include exhaust fan, HEPA filter, reheater, condenser and demister. Typical installations on the type IV tanks include exhaust fan, HEPA filters and reheater. The exception to this arrangement are tanks 17/19, 18, 20, 21 and 24 which, in addition, have a shell type demister. The ventilation system of pump tanks, pump pits and diversion boxes in some cases has exhaust fan, HEPA filter, reheater, condenser and demister and in other cases exhaust fan and HEPA filter only.

The $\mathrm{H}$ and $\mathrm{F}$ area tank farm evaporator cell exhaust systems that do not have condensers, preheaters or demisters are not considered in this report.

It is desirable to maintain continuous operation of all ventilation systems. The governing principle is that interruptions should be minimized. Whenever prolonged outages are unavoidable, restart of normal purge or installation of a portable ventilation is initiated per operating procedures (Reference procedures: 241-F-131Q, 241-H-131Q 241-FH-120TQ and 241FH-150TQ) if the system shutdown approaches 7 days (per the draft OSR, Reference 3) or the buildup of hydrogen reaches 10\% LFL as controlled by operating procedures. Alarm signals are provided for all systems to indicate failure of blower. The condition of other equipment is observed periodically by patrolling operators. When an adverse condition is discovered by signal or observation, an attempt is made to restore normal operation. If that attempt is unsuccessful, arrangements are set up to monitor the affected process equipment and parameters frequently. During any such interval of ventilation outage, periodic tests are made by Radiation Control personnel to determine the combustible vapor content of the interior tank space (to recognize an approach toward the lower explosive limit).

Exhaust air from each waste tank is sampled continuously or periodically to determine its level of radioactivity even though it is well below environmental release guide values. All Type III and IIIA tanks are provided with continuous air monitor (CAM) for effluent air. The remaining tanks are equipped with air sampler. Instrumentation to continuously monitor the concentration of hydrogen in the gas mixture is provided within each Type III \& IIIA tank and tanks $4 \& 13$. The remaining tanks do not present a potential of high hydrogen generation because the heat content is so low. Even with loss of ventilation, it would be months before sufficient hydrogen would accumulate to reach the lower flammability limit. Radiation Control checks for flammable gases are conducted on a schedule as outlined in 241-FH-1310TQ

\section{Ventilation of Waste Tank Vapor Space:}

The interior of the primary containment vessel of each waste storage tank is ventilated continuously with purge sweep of air which flows at a rate of nominally 100 to 300 CFM through the waste tank vapor space. This purge flow maintains the concentration of hydrogen which is generated continuously by radiolytic decomposition of waste water, well below the explosive limit.

To reduce escape of entrained contamination, purge air is exhausted through HEPA filters for all tanks. The air stream entering the exhaust filters are steam heated to prevent condensation of moisture, which could cause a high differential pressure across the filter, or which might damage the filter. HEPA filters are subject to gross breaching only if wet for long period of time and/or HEPA filter $\mathrm{dP}$ is $10^{\prime \prime}$ WC or greater. 
WSRC-TR-94-0506, Rev. 0

Page 4 of 8

$4 / 10 / 95$

The typical air flow path enters the interior space through the purge air inlet plenum. The air flows through a demister that intercepts droplets of water and returns them to the tank. Depending on the type of tank, the demister is either installed in the riser before the condenser (type III \& IIIA) or it can be a shell type demister. The air flow then goes through a water cooled condenser to extract potentially radioactive moisture (if applicable), through a preheater to raise the air temperature above its dew point (to prevent water vapor from condensing in the HEPA filters) and through the HEPA filters to remove particulate. The air is finally discharged to the atmosphere through the exhaust blower.

\section{Ventilation of Unconcentrated Waste Transfer Pump Tanks and Pits:}

The pump tanks and their enclosures (called "pits") are maintained at a slight negative pressure to diminish the possibility for outward migration radioactivity. Air flows into the pump pits through HEPA filters and then enters the pump tanks by way of their overflow lines. $\mathrm{F}$ area pump pits 2 and 3 and $\mathrm{H}$ area pump pits 5 and 6 are equipped with complete ventilation systems, including demisters, condensers, reheaters and HEPA filters.

Air for $\mathrm{H}$ area pump pits 5 and 6 enters directly through the dust stop filter before passing into the corresponding pump tanks, respectively, then exits through the ventilation exhaust manifold.

The $\mathrm{F}$ area waste transfer pump tanks and pump pits are ventilated by air flows entering through associated diversion boxes and exiting to the atmosphere through HEPA filter units. Air for FPT-1 enters through FDB-2 and air for FPT-2 and 3 enters through FDB-4. In both cases, the air enters by way of inlet duct filters and exits through demister, condenser, reheater, HEPA filter and exhaust fan assemblies. FDB-5 and FDB-6, which also have forced ventilation system, do not have a condenser or demister.

$\mathrm{H}$ area pump tanks are ventilated somewhat differently than those in F area. Air for HPT-1 through 4 and HDB-2 enters through dust stop filters. Air flows from DB-2 via its drain line into pit 4 and from transfer pits 2 through 4 into the respective pump tanks, and into the ventilation exhaust manifold. Air flows from HPP-1 through wall nozzles directly to the ventilation exhaust manifold, since HPP-1 has no pump tank installed. The exhaust air is heated in a steam-jacketed pipe to prevent condensation in the fiberglass exhaust filter. A HEPA filter was added downstream of the fiberglass filter. HDB-6 and HDB-7, which also have a ventilation system, do not have a condenser or demister.

\section{Ventilation of Concentrated Waste Transfer Systems:}

The concentrate pump tanks and pump pits are controlled at a slightly negative pressure with respect to the atmosphere to reduce the release of airborne radioactivity. Air flow is also regulated to limit the temperature, below $125^{\circ} \mathrm{F}$ in pump pits for the protection of electrical equipment (Reference 1).

There are two separate exhaust systems, one for the pump tank and one for the pump pit. The pump tanks are maintained at a slightly lower pressure than the pump pits. In the $F$ area system, exhaust air of the pump tank is passed through a condenser, demister, reheater, HEPA filter assemblies then exhausted by fans to the atmosphere. In $\mathrm{H}$ area system, this sequence is preceded by another demister. 
WSRC-TR-94-0506, Rev. 0

Page 5 of 8

$4 / 10 / 95$

Air enters the pump pits through a dust stop filter. Some air also enters the pit through cracks around concrete cell covers. An automatic damper regulates air flow leaving the pits, except for F area F-CTS which uses a manual damper. A steam coil is installed upstream of the exhaust HEPA filter to prevent condensate from wetting and plugging the filter. Exhaust filters and exhaust blowers are provided in two parallel systems to ensure continuous operation and to provide additional capacity if needed. Manual dampers and a crossover duct are provided for flexibility of operation and for isolation of filters during replacement.

\section{Emergency Ventilation Equipment:}

Emergency ventilation equipment consists of exhaust blower, HEPA filter, flexible duct and portable electrical generator (Reference 4). Procedures and portable equipment for emergency ventilation of the waste tanks are available for use in the event of failure of a permanent ventilation system. For cases in which the system cannot be promptly repaired, hydrogen buildup in the tank is monitored, and a portable blower is installed within seven (7) days to the existing system or through a tank riser utilizing a portable blower and a temporary HEPA filter unit (Reference procedures: 241-F-131Q, 241-H-131Q, 241-FH-120TQ and 241-FH-150TQ).

\section{DISCUSSION}

Loss of Chromate Cooling Water:

Loss of chromate cooling water will prevent the water cooled condenser from performing its intended function of condensing excess moisture out of the air stream. This will cause the demisters, if installed, down stream of the condenser to collect excess moisture, which in turn may cause the demister $\mathrm{dP}$ to increase and potentially saturate the HEPA filter. The purge exhaust fan can continue to operate while compensatory action is taken to increase the monitoring of the demister dP. If the demister dP reaches the upper limit, the system is considered operable as long as the tank vacuum is maintained within current procedural limits and the HEPA filter is below its upper dP limit; inoperable when the HEPA filter is at its upper dP limit and/or tank vacuum is below its lower limit. Although HLWE conservatively defines system inoperability if HEPA filter dP is out of limit high, OSR compliance is maintained due to the fact that air flow, tank vacuum, LFL Hydrogen less than $10 \%$, Hydrogen monitoring, Radiation monitoring, HEPA filter DOP tested initially and backup portable ventilation are maintained.

\section{Ioss of Steam:}

Loss of steam will prevent the reheater from performing its intended function of raising the temperature of the air stream above the dewpoint to prevent condensation on the HEPA filter. Condensation built up on HEPA filter media will cause the filter dP to increase. The purge exhaust fan can continue to operate while compensatory action is taken to increase the monitoring of the HEPA filter $\mathrm{dP}$ as long as the tank vacuum is maintained within current procedural limits. If the HEPA filter dP reaches the upper limit the system is considered inoperable. Although HLWE conservatively defines system inoperability if HEPA filter $\mathrm{dP}$ is out of limit high, OSR compliance is maintained due to the fact that air flow, tank vacuum, LFL Hydrogen less than $10 \%$, Radiation monitoring, HEPA filter DOP test are maintained. 
WSRC-TR-94-0506, Rev. 0

Page 6 of 8

$4 / 10 / 95$

Loss of Chromate Cooling Water and Steam:

If both chromate cooling water and steam is lost, then the water cooled condenser cannot condense excess moisture from the air stream and the reheater cannot raise the

temperature of the air stream above the dewpoint. The $\mathrm{dP}$ for the demister, if installed, and the HEPA filter may increase. The purge exhaust fan can continue to operate while compensatory action is taken to increase the monitoring of the HEPA filter dP. If the demister dP reaches the upper limits the system is considered operable as long as the tank vacuum is maintained within current procedural limits and the HEPA filter dP does not exceed the upper limit. If the HEPA filter reaches the upper limit, the system is considered inoperable. Although HLWE conservatively defines system inoperability if HEPA filter dP is out of limit high, OSR compliance is maintained due to the fact that air flow, tank vacuum, LFL Hydrogen less than 10\%, Radiation monitoring, HEPA filter DOP test are maintained.

With any of the above conditions occurring, HEPA filter $\mathrm{dP}$ must be closely observed when the upper $\mathrm{dP}$ limit is approached for the following reasons:

1. As the HEPA filter is saturated with excess moisture for long periods of time and the filter $\mathrm{dP}$ reaches the upper limit, there is a potential for gross breaching of the HEPA filter if the blower is capable of pulling more than 10" WC.

2. The air flow could go below 100 CFM as the filter $\mathrm{dP}$ reaches the upper limit and possibly cause the tank vacuum to go below the current operating procedure limit.

The following expected consequences could be experienced if any of the above conditions occur:

1. Condensed water could be found on instruments (CAM/air sampler system and gauges).

2. Saturated air in the form of a mist could be discharged from the blower stack.

3. Contamination is released if HEPA filter is breached. This is not likely to occur for the low pressure (vacuum) system (9" WC or less).

\section{Transfers:}

During emergency transfers (defined as Technical Standard - required transfers associated with leaking tanks - "If a leak of $1.0 \mathrm{gpm}$ or greater is verified in the primary container of any waste tank, emptying of the tank (if single-wall) or annulus (if double-wall) must be initiated within 24 hours from the time the leak is verified. Emtying of the annulus must continue until leakage stops. The tank must be emptied as soon as practicable to a level where the leakage stops or until all supernate liquid and as much interstitial liquid as possible is removed" (see DPSTS-241-1.01, paragraph C.5a). Loading of the HEPA filter as a result of loss of chromate cooling water to the condenser and/or loss of steam to the HEPA filter preheater could cause the HEPA filter $\mathrm{dP}$ to reach its upper limit (this could result in gross breaching of the HEPA filter if the blower is capable of pulling more than $10^{\text {" }} \mathrm{WC}$ ), the emergency transfer can continue while implementing continuous monitoring. If CAM alarm or filter paper analysis indicates high activity, and the transfer can be stopped for a short period of time without risking a liquid release to the environment from the leaking tank, then the transfer should be shut down, a portable blower, HEPA filter and portable air sampler should be installed and the transfer should be restarted. However, if stopping the transfer would result in a liquid release to the environment from the leaking tank, then the transfer should continue regardless of the indication of high activity from the CAM alarm or filter paper analysis (References $3 \& 5$ ).

During normal transfers, it is conservative not to operate the purge exhaust system without chromate cooling water in service to the condenser and steam heat to the HEPA filter preheater in service. It is recommended that the transfer be delayed until all the components to the purge exhaust system are available for service, however not essential as long as other parameters are verified to remain in limits. 
WSRC-TR-94-0506, Rev. 0

Page 7 of 8

$4 / 10 / 95$

HEPA Filters and the Wicking Phenomena:

Each HEPA filter is tested by the manufacturer for at least one hour with a dP of 10 " wc (Reference 8). This test is to prove the HEPA filter can withstand this dP and not burst through. There is a possibility of water from condensation accumulating at the bottom of the HEPA filter unit and this water passing through to the downstream side of the HEPA filter, carrying contamination with it. This is possible because the particulate becomes water soluble and passes through the HEPA filter in the water stream, and when the water evaporates the particulate will become free and travel with the airstream. With the increased surveillance of HEPA filter $\mathrm{dP}$ and air sampler filter paper, this will not be an operational concern, unless the air sampler filter paper/or the CAM indicates contamination. It is noted that the potential for water soluble particles (ex: Cesium) migrating through the HEPA filter medium is very minimal.

Based on Reference 6 and 7, the OSR requirement for surveillance testing the inlet HEPA filters and HEPA filters in the uncontaminated exhaust stream every 12 months is no longer interpreted as a requirement. The Interpretation of OSR (Reference 4) requires functional testing of the backup ventilation every three months and the OSR (Reference 2) requires a DOP test on the HEPA filters in the contaminated exhaust air stream (including backup ventilation system, when installed) every 12 months.

\section{Compensatory Actions}

1. If steam is lost to the reheater and/or cooling water is lost to the condenser, then operator rounds are increased to every 4 hours to monitor the HEPA filter $\mathrm{dP}$ (procedures 241-FH-150TQ and 241-FH-150A-TQ).

2. If the HEPA filter $\mathrm{dP}$ is at the upper limit, then swap to the backup HEPA filter unit, if installed, or take the purge exhaust system out of service, initiate hydrogen monitoring and replace the HEPA filter per 241-FH-210S. Return the purge exhaust system back into operation within seven (7) days or install portable ventilation system per applicable procedure.

\section{ACTIONS}

1. A PCR to be issued against 241-F-131Q to allow the ventilation system startup without chromate cooling water valved in, if the cooling water system is out of service.

NOTE: All other required actions that must be incorporated are already added to the appropriate procedures (i.e.: initiating manual hydrogen sampling if LFL reaches its limit) to cover the philosophy of this report.

\section{REFERENCES}

1. DPSTSA-200-10, SUP-18, Safety Analysis Report.

2. DPW-86-103, Rev. 1, Operational Safety Requirements, Issued July 1986, Revised February 23, 1989.

3. WSRC-RP-92-1044, Operational Safety Requirements, DOE Approval Draft, 9/7/93.

4. HLW-REG-94-0096, Rev. 1 Interpretation of OSR 4.1.C.1 (U), March 17, 1995. 
WSRC-TR-94-0506, Rev. 0

Page 8 of 8

$4 / 10 / 95$

5. DPSTS-241, Technical Standard, November 1988.

6. HLW-REG-940051, DOP Testing of HEPA Filters at the Tank Farm Memo from R.M. Satterfield, March 31, 1994.

7. G-TRC-H-01554 and G-TRC-F-00119 Technical Reviews, HEPA Filter DOP Test Requirements.

8. MIL-F-51068F, Military Specification, Filter Particulate, High Efficiency, Fire Resistant, March 1986.

9. WSRC-TR-94-067, Rev. 1, Resolution of the Hydrogen Deflagration Accident Scenario, August 1994.

10. 241-FH-12OTQ, Rev. 15, IPC 94-182-1H \& 94-191-1H, Action to be Taken when LFL Hydrogen is Detected in a Waste Tank.

11. 241-F-131Q, Rev. 0, IPC 94-242-2F, E Area Pump Pits 2 \& 3 and FDB-4 Purge System Operation.

12. 241-H-131Q Rev.1, IPC 94-288-2H, Waste Receipt Pump Tank Purge System Operation.

13. 241-FH-150TQ Rev. 23, IPC 94-300-1H, Waste Tank Purge Blower Startup and Shutdown.

14. 241-FH-214, Rev. 4, Purge Exhaust System Operation.

15. 241-FH-1310TQ Rev. 2, IPC 94-283-1H, 93-461-1H \& 94-268-1H, Manual Sampling for Hydrogen. 